Omni-Akuatika, 12 (3): 119 - 130, 2016
ISSN: 1858-3873 print / 2476-9347 online
Research Article

\title{
Upwelling di Laut Banda dan Pesisir Selatan Jawa serta Hubungannya dengan ENSO dan IOD
}

\author{
Herlina Ika Ratnawati ${ }^{1,2}$, Rahmat Hidayat ${ }^{1}$, Ahmad Bey ${ }^{1}$, Tania June ${ }^{1}$ \\ ${ }^{1}$ Departemen Geofisika dan Meteorologi, Institut Pertanian Bogor, Kampus IPB Dramaga,Bogor, 16680, \\ Indonesia \\ ${ }^{2}$ Pusat Penelitian dan Pengembangan Sumberdaya Laut dan Pesisir, Balitbang-KP, Kementerian Kelautan dan \\ Perikanan, Jl. Pasir Putih I Ancol Timur, Jakarta, Indonesia \\ "Corresponding author: herlina.ir@gmail.com
}

\begin{abstract}
Upwelling events analysis in southern coast of Java and Banda sea were conducted. The events were identified by using satellite data i.e. wind surface, Sea Surface Temperature (SST) and ocean color during period of 14 years (2002-2016) which calculated by Ekman pumping and Ekman transport. It's found that Ekman pumping velocity in Banda Sea reached a maximum in June-July-August (JJA) by approximately $3,65 \times 10^{-6} \mathrm{~ms}^{-1}$. Comparing with Ekman transport, Ekman pumping makes an even greater contribution to the local upwelling in Banda Sea. Ekman pumping velocity in southern coast of Java reached a maximum in June-July-August (JJA) by approximately $4,9 \times 10^{-6} \mathrm{~ms}^{-1}$. Ekman pumping and Ekman transport makes an equal contribution to coastal upwelling in southern coast of Java. That's related to highest clorophyll-a concentration apperars in JJA periode. Partial correlation analysis then was applied to identify a correlation between chlorophyll-a concentration and interannual climate variabilities such as ENSO and IOD. Partial Correlation between chlorophyll-a and Nino 3.4 and DMI-Dipole Mode Index (controlled) in Banda Sea is 0.18 , and 0.05 in southercoast of Java. It's represent ENSO (Elnino Southern Oscilation) has higher influences to Banda Sea than southern coast of Java. Partial correlation between chlorophyll-a and DMI and Nino 3.4 (controlled) is 0.55 in southern coast of Java, and 0.25 in Banda Sea. Its represent IOD (Indian Ocean Dipole) has higher influences to southern coast of Java than Banda Sea. Upwelling in Banda sea and along southern coast of Java dominantly occurs in southeast monsoon as a responds to regional wind driven motion associated with the monsoon climate. Various condition of chlorophyll-a booming also occured according to combination of ENSO and IOD events.
\end{abstract}

Keywords: upwelling, Banda sea, southern coast of Java, Ekman transport, Ekman pumping, IOD, ENSO

\section{Pendahuluan}

Benua Maritim Indonesia (BMI), secara geografis terletak di daerah tropis berada di antara Samudera Pasifik dan Samudera Hindia serta diantara benua Asia dan Australia. Posisi BMI yang strategis inilah yang menjadikan kondisi atmosfer dan lautan sangat kompleks dalam mengendalikan sirkulasi atmosfer regional dan global. Berbagai sirkulasi global atmosfer dan laut yang melintasi wilayah BMI menyebabkan tingginya variabilitas iklim di atasnya.

Wilayah perairan laut BMI juga dipengaruhi keragaman variabilitas lautatmosfer. Berbagai fenomena yang memiliki siklus beragam baik secara spasial dan temporal mempengaruhi kondisi atmosfer di BMI, diantaranya adanya sistem monsunal, aliran Arus Lintas Indonesia (Arlindo) -
Indonesia Trough Flow (ITF), serta sirkulasi laut-atmosfer global yang terkait dengan fenomena ENSO, IOD dan Madden Julian Oscillation (MJO). Variabilitas laut dan atmosfer dapat teridentifikasi dari beberapa parameter seperti kondisi hujan, angin, suhu permukaan laut (SPL) -sea surface temperature (SST). Selain proses fisis diatas, proses biologiskimiawi di BMI juga dipengaruhi oleh variabilitas laut dan atmosfer.

Fitoplankton sebagai tumbuhan sel tunggal berukuran mikroskopik memiliki peran penting proses kehidupan di dalam perairan dan berfungsi sebagai sumber makanan organisme perairan yang dapat digunakan sebagai salah satu kajian untuk menduga sebaran konsentrasi klorofil-a (chlorophyll-a) pada perairan (Putra, 2012). Kandungan chlorophyll-a juga digunakan sebagai ukuran jumlah fitoplankton pada suatu perairan dan 
dapat digunakan sebagai petunjuk produktifitas suatu perairan. Perlunya mengkaji distribusi konsentrasi chlorophyll-a karena dapat dijadikan sebagai suatu indikator dalam menentukan tingkat kesuburan perairan laut (Hendiarti, et al., 2004). Dengan mengetahui daerah yang memiliki tingkat kesuburan tinggi maka dapat diduga berpotensi sebagai wilayah penangkapan ikan. Chlorophyll-a memiliki variabilitas secara spasial dan temporal. Variasi spasial distribusi chlorophyll-a di lautan tergantung pada letak geografis dan kedalaman perairan. Variasi ini disebabkan oleh perbedaan intensitas cahaya matahari dan konsentrasi nutrien di perairan.

Upwelling merupakan suatu proses naiknya massa air laut dari lapisan dalam laut ke permukaan. Adanya angin yang mendorong lapisan air pada permukaan mengakibatkan kekosongan massa air di bagian atas, akibatnya air yang berasal dari bawah menggantikan kekosongan yang berada di atas. Gerakan naik ini membawa serta air yang suhunya lebih dingin, salinitas tinggi, dan zatzat hara yang kaya ke permukaan (Nontji, 1993 dalam Putra, 2012). Proses upwelling dapat terindikasi dari sebaran konsentrasi chlorophylla yang bervariasi secara spasial dan temporal. Konsentrasi chlorophyll-a lebih tinggi pada perairan pantai dan pesisir, serta rendah diperairan lepas pantai, namun pada daerahdaerah tertentu di perairan lepas pantai dijumpai konsentrasi chlorophyll-a dalam jumlah yang cukup tinggi, yang merupakan fenomena upwelling (Ramansyah, 2009).

Pada sektor kelautan dan perikanan, variabilitas laut-atmosfer banyak dikaji dalam kaitannya dengan distribusi konsentrasi chlorophyll-a. Susanto et al. (2001a, 2001b) serta Susanto dan Marra (2005) menganalisis kejadian fenomena EI Nino Southern Oscillation (ENSO) 1997/1998 melalui pengamatan satelit ocean color (chlorophyll-a) di perairan laut Indonesia, dimana El Nino kuat pada 1997/1998 diikuti dengan periode La Nina, yang juga bertepatan dengan kejadian Indian Ocean Dipole (IOD) positif, berkaitan dengan tingginya nilai chlorophyll-a (upwelling) di sepanjang pantai selatan Jawa dan Sumatera. Nilai chlorophyll-a juga terlihat lebih tinggi saat berlangsungnya monsun timur (April-Oktober) dibandingkan saat monsun barat. Menurut Purwandani (2012), variabilitas laut-atmosfer dan proses dinamika interaksi antara Monsoon, Dipole Mode (DM) dan ENSO secara simultan terhadap SPL di perairan Asia Tenggara dan sekitarnya, total keragaman terbesar pertama (mode-1) dari SPL didominasi oleh siklus tahunan muson dengan periode sebesar 12,2 bulan. Mode-2 merupakan penyimpanan/pelepasan Bahang perairan Asia Tenggara (PBAT) dengan fenomena yang mengiringi masih didominasi oleh monsoon dan munculnya siklus dekadal serta siklus dua tahunan. Sementara mode-3 berkaitan dengan siklus antar tahunan dengan periode 42,6 bulan.

Beberapa penelitian terkait sebaran chlorophyll-a dan variabilitas iklim yang telah dijelaskan diatas memberikan kontribusi pada perkembangan keilmuan iklim dan kelautan di Indonesia. Namun, kajian yang dilakukan tersebut masih bersifat parsial, artinya masih terfokus pada satu atau dua kombinasi dari fenomena yang terjadi di BMI. Penelitian ini bertujuan untuk menganalisis karakteristik upwelling di Laut Banda dan Selatan Jawa, serta menganalisis hubungan antara chlorophyll-a dengan variabilitas iklim antar tahunan ENSO dan IOD. Studi ini sangat penting dalam perkembangan iklim kelautan sehingga hasilnya diharapkan dapat memberikan kontribusi terhadap pengelolaan sektor kelautan dan perikanan terkait dengan Wilayah Pengelolaan Perikanan (WPP-RI), sebagaimana Indonesia sebagai poros maritim.

\section{Data dan Metode Penelitian}

Data

Daerah penelitian meliputi wilayah perairan BMI, dengan koordinat $90^{\circ}-150^{\circ} \mathrm{BT}$ dan - $15^{\circ} \mathrm{LU}-15^{\circ} \mathrm{LS}$, khususnya di Laut Banda $\left(3,5^{0}-7^{0} \mathrm{LS} ; 126^{\circ}-131^{\circ} \mathrm{BT}\right)$ dan perairan Selatan Jawa $\left(105^{0}-115^{\circ} \mathrm{BT} ; 7^{0}-9^{0} \mathrm{LS}\right)$. Data yang digunakan dalam penelitian ini adalah data suhu permukaan laut (SPL) dan angin permukaan dengan resolusi $0,125^{\circ}$ yang diunduh dari laman http://www.ecmwf.int/, Data konsentrasi chlorophyll-a dengan resolusi $4 \mathrm{~km}$ dari laman http://oceancolor.gsfc.nasa.gov/, (Hu, el al., 2012). Dipole Mode Index (DMI) merupakan indikator yang digunakan untuk mengidentifikasi fenomena IOD, data ini diperoleh dari laman http://www.jamstec.go.jp/. Fenomena ENSO diidentifikasi mengunakan data indeks Nino 3.4 yang diunduh dari laman http://iridl.Ideo.columbia.edu/. Periode data chlorophyll-a, SPL dan angin yang digunakan dalam penelitian ini mulai Juli 2002 hingga Januari 2016.

\section{Metode penelitian}

Analisis data dilakukan dengan menggunakan analisis komposit. Analisis ini merupakan suatu teknik penarikan contoh kemungkinan berdasarkan kondisi rata-rata 
beberapa fenomena tertentu yang sama sehingga hasilnya dapat mewakili secara umum perkiraan waktu yang menunjukkan fenomena tersebut (Nur'utami dan Hidayat, 2015).

Data SPL, angin permukaan dan chlorophyll-a dilakukan analisis komposit pada setiap bulannya, dan dikelompokkan dalam empat musim yaitu Desember-Februari (DJF), Maret-Mei (MAM), Juli-Agustus (JJA), dan September-November (SON). Metode analisis ini mengacu pada beberapa penelitian sebelumnya yang menyatakan bahwa dampak kejadian coastal upwelling dapat dianalisis dengan menganalisis sebaran SPL dan chlorophyll-a yang ada di permukaan perairan (Yunwei et al. (2015), Susanto et al. (2001a, 2001b) ; Susanto dan Marra (2005)).

Fenomena upwelling dapat dikuantifikasi melalui perhitungan ekman pumping yang berhubungan dengan ekman transport di wilayah penelitian (Yunwei et al. 2015; Tubalawony 2007). Langkah awal yang dilakukan dalam perhitungan ekman transport dan ekman pumping adalah menghitung gesekan angin (wind stress) dan wind stress curl untuk setiap komponen angin pada wilayah penelitian (Pickett dan Paduan, 2003). Asumsi yang digunakan yaitu komponen angin sumbu $x$ dengan arah sejajar pantai (zonal) dan komponen angin sumbu y dengan arah menegak pantai (meridional). Ekman transport $M_{E}$ dan ekman pumping $W_{E}$ dihitung dengan persamaan (Smith. 1968, dalam Yunwei et al. 2015) sebagai berikut:

$$
\begin{aligned}
& M_{E}=\frac{1}{\rho f} \vec{\tau} \times \hat{t} \\
& W_{E}=\frac{1}{\rho f} \nabla \times \vec{\tau}
\end{aligned}
$$

dengan $\vec{\tau}$ adalah vektor wind stress, $\hat{t}$ adalah vektor satuan yang bersinggungan dengan garis pantai, $\rho$ adalah densitas air laut dan $f$ adalah parameter Coriolis.

Besarnya gesekan angin (wind stress), $\tau=\left(\tau_{x}, \tau_{y}\right)$ pada permukaan laut dihitung dari data kecepatan angin permukaan $10 \mathrm{~m}$ dengan menggunakan persamaan (Kutsuwada 1998, Tubalawony 2007,):

$$
\tau=\rho_{u} C_{D}\left|\overrightarrow{v_{H}}\right| v_{H}
$$

dengan $\tau_{x}=\rho_{u} C_{D}\left|\overrightarrow{v_{H}}\right| U$

$$
\tau_{y}=\rho_{v} C_{D}\left|\overrightarrow{v_{H}}\right| V \quad \text { (3b). }
$$

dan

Besarnya ekman transport untuk komponen sejajar dan menegak pantai dihitung dari wind stress. Ekman pumping dihitung dari wind stress curl. $W_{E}$ adalah kejadian ekman pumping sebagai kecepatan vertikal pada dasar lapisan ekman yang dihubungkan dengan konvergensi atau divergensi ekman transport. Nilai ekman pumping bertanda negatif $W_{E}<0$ menunjukkan adanya konvergensi ekman transport pada permukaan yang menggerakkan massa air menuju dasar laut disebut sebagai downwelling. Jika nilai ekman pumping bertanda positif $W_{E}>0$ menunjukkan adanya divergensi ekman transport pada permukaan yang menggerakkan massa air menuju permukaan laut disebut sebagai proses upwelling. Nilai ekman transport dan ekman pumping dapat digunakan untuk merepresentasikan pergerakan kejadian coastal upwelling.

Variabilitas iklim di wilayah BMI meliputi variasi iklim musiman (seasonal), intramusiman (intraseasonal) dan non-musiman (nonseasonal) yang meliputi variasi antar tahunan (interannual). Pengaruh monsun yang dominan besar dampaknya terhadap sektor kelautan. Salah satunya adalah kelimpahan chlorophyll-a terlihat lebih tinggi pada saat monsun timur dibandingkan pada saat berlangsungnya monsun barat (Susanto et al. (2001a, 2001b); Susanto dan Marra. 2005).

Variasi interannual di Indonesia dipengaruhi oleh El Nino dan Dipole Mode. ENSO merupakan fenomena interaksi antara laut dan atmosfer di Samudera Pasifik, dimana El Nino merupakan fenomena lautan sedangkan Southern Oscillation adalah fenomena terkait atmosfer. Kejadian El-Nino di Indonesia dapat diidentifikasi dari Nino 3.4 index sebagai rata-rata anomali SST di wilayah Nino 3.4 yaitu pada koordinat $120^{\circ}-170^{\circ} \mathrm{BB}$ dan $5^{\circ}$ LU-5 $5^{\circ}$ LS, (Susanto dan Marra, 2005). Anomali suhu permukaan laut di Pasifik Ekuator berkaitan erat dengan sirkulasi Walker. Daerah dengan suhu permukaan laut tinggi merupakan pusat tekanan udara rendah dan merupakan daerah konvektif, sehinga menjadi penggerak utama sirkulasi Walker selanjutnya.

Indian Ocean Dipole Mode (IODM) adalah sebuah fenomena samudera dan atmosfer di Samudera Hindia ekuator yang ditandai dengan anomali negatif suhu permukaan laut di Sumatera dan anomali suhu positif di bagian barat Samudera Hindia (Saji et al. 1999). IOD merupakan fenomena interannual di Samudera Hindia, serta memiliki fase positif dan fase negatif. Fase IOD positif terjadi ketika suhu permukaan laut turun di bagian selatan-timur samudera Hindia di bagian pantai utara Australia, pantai timur Jepang, dan Indonesia. Kemudian diikuti dengan fase negatif berupa meningkatnya suhu permukaan laut di bagian barat timur Afrika dari sebagian pantai utara Madagaskar sampai pantai utara tepi Somalia. Indikator yang digunakan untuk mengidentifikasi fenomena IODM adalah Dipole 
Mode Index (DMI). DMI positif disebut dengan IODM positif, sedangkan DMI negatif disebut sebagai IODM negatif. Kejadian IOD didentifikasi dari IOD Index sebagai perbedaan SST anomali antara Samudra Hindia tropis bagian barat $\left(50^{\circ}-70^{\circ} \mathrm{BT}, 10^{\circ} \mathrm{LU}-10^{\circ} \mathrm{LS}\right)$ dan Samudra Hindia tropis bagian tenggara $\left(90^{\circ}\right.$. $110^{\circ} \mathrm{BT}, 10^{\circ}$ LS-ekuator).

Untuk mengetahui hubungan antara kelimpahan konsentrasi chlorophyll-a dengan variabilitas iklim antar-tahunan ENSO dan IOD dianalisis dengan analisis korelasi tunggal dan korelasi parsial. Analisis korelasi parsial digunakan untuk mengidentifikasi kuat lemahnya hubungan antar variabel bebas dan variabel terikat, dimana variabel bebas lainnya dikontrol atau dianggap berpengaruh (Irianto 2006). Untuk menghitung koefisien korelasi parsial, terlebih dahulu dilakukan perhitungan korelasi tunggal dengan persamaan:

$r=\frac{n \sqrt{X Y}-\left(\sum X\right)\left(\sum Y\right)}{\sqrt{\left\{n \sum X^{2}-\left(\sum X\right)^{2}\right\}\left\{n \sum Y^{2}-\left(\sum Y\right)^{2}\right\}}}$

dengan $\mathrm{n}$ adalah jumlah data; $X$ adalah variabel bebas dan $Y$ adalah variabel terikat.

Selanjutnya perhitungan koefisien korelasi parsial dapat digunakan persamaan:

$r_{y . x_{1}-x_{2}}=\frac{r_{y x_{1}}-r_{y x_{2}} r_{x_{1} x_{2}}}{\sqrt{1-r^{2} x_{1} x_{2}} \sqrt{1-r^{2} y x_{2}}}$

dengan $r_{y x_{1}}$ korelasi antara variabel terikat $Y$ dengan vriabel bebas $X_{1} ; r_{y x_{2}}$ korelasi antara variabel terikat $Y$ dengan variabel bebas $X_{2}$; dan $r_{x_{1} x_{2}}$ korelasi antara variabel bebas $X_{1}$ dengan variabel bebas $X_{2}$.

\section{Hasil dan Pembahasan}

Variasi SPL, angin permukaan, Ekman transport, Ekman pumping dan chlorophyll-a

Wilayah perairan di Laut Banda dan selatan Jawa merupakan daerah kajian yang menarik, karena memiliki variabilitas spasial dan temporal yang terlihat jelas dari distribusi chlorophyll-a, SPL dan angin permukaan. Gambar 1 memperlihatkan komposit distribusi chlorophyll-a pada setiap musim di selatan Jawa. Konsentrasi chlorophyll-a pada periode monsun barat (DJF) berkisar $0,34 \mathrm{mg} / \mathrm{m}^{3}$ dan pada MAM sebesar $0,36 \mathrm{mg} / \mathrm{m}^{3}$. Pada periode monsun timur (JJA) konsentrasi chlorophyll-a meningkat menjadi $0,89 \mathrm{mg} / \mathrm{m}^{3}$ dan pada SON mencapai nilai $1,1 \mathrm{mg} / \mathrm{m}^{3}$. Konsentrasi chlorophyll-a pada periode SON terlihat lebih tinggi dan terdistribusi lebih luas hingga mencapai $200 \mathrm{~km}$ dari tepi pantai dibandingkan pada periode JJA. Hasil komposit distribusi SPL dan angin permukaan ditunjukkan pada Gambar 2. SPL pada periode JJA dan SON mencapai $27^{\circ} \mathrm{C}$ yang terdistribusi luas pada periode JJA dan mulai berkurang pada periode SON. Hasil komposit angin bulanan memperlihatkan angin tenggara dengan kecepatan yang lebih tinggi di perairan selatan Jawa pada periode JJA dan mulai menurun pada periode SON. Sementara kecepatan angin pada saat DJF cenderung semakin menurun dan mencapai nilai minimum pada periode MAM.

Kondisi SPL rendah dan kecepatan angin permukaan yang relatif lebih tinggi pada periode JJA bertepatan dengan kelimpahan konsentrasi chlorophyll-a dipesisir selatan Jawa merupakan indikasi terjadinya upwelling. Pada periode SON kelimpahan chlorophyll-a terlihat lebih tinggi dan terdistribusi meluas hingga ke pesisir barat daya Sumatera. Kondisi ini terkait dengan SST yang lebih dingin meluas hingga ke pesisir barat Sumatera. Persistensi angin timuran yang kuat ini bertindak sebagai winddriven motion pada fenomena upwelling saat monsun timur. Kondisi SST dingin membawa massa air yang kaya nutrien menuju permukaan laut terindikasi dari kelimpahan konsentrasi chlorophyll-a. Gerakan naiknya massa air ini juga diakibatnya karena adanya stratifikasi lapisan yang memiliki perbedaan densitas pada setiap lapisannya karena dengan bertambahnya kedalaman perairan maka suhunya akan semakin turun dengan densitas makin meningkat. Hal ini memicu energi untuk menggerakkan massa air secara vertikal.

Sebaliknya, pada saat DJF kelimpahan konsentrasi chlorophyll-a cenderung menurun dimana SPL mengalami peningkatan sementara kecepatan angin mengalami penurunan. Hal ini mengindikasikan terjadinya proses downwelling di wilayah pesisir tersebut. 


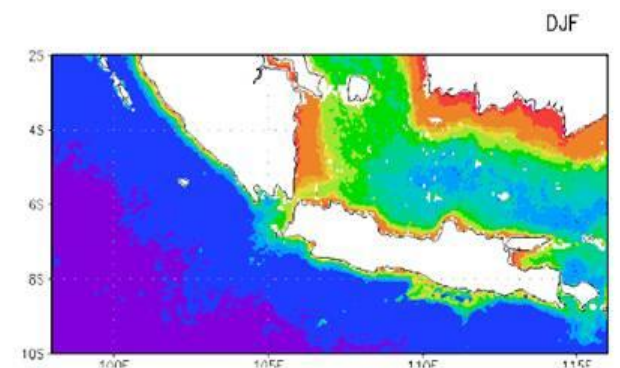

JJA

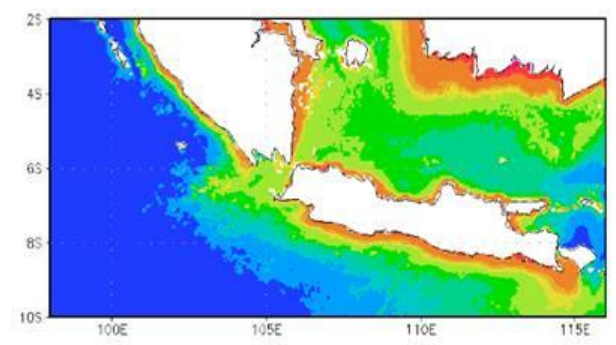

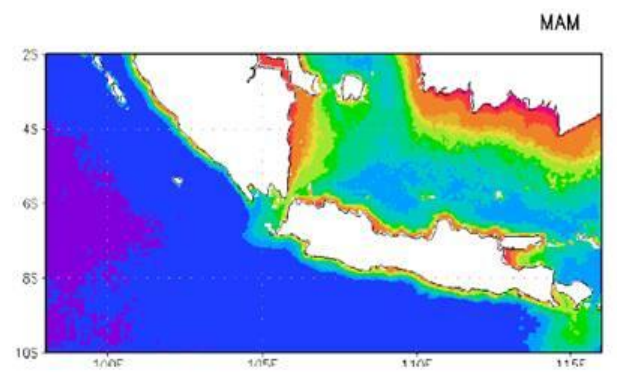

SON

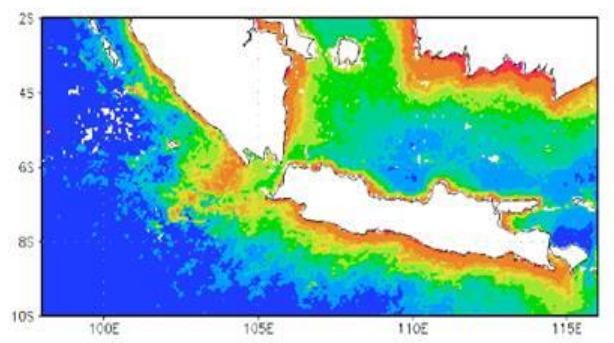

$\left(\mathrm{mg} / \mathrm{m}^{3}\right)$

Gambar 1. Komposit chlorophyll-a musiman di selatan Jawa.

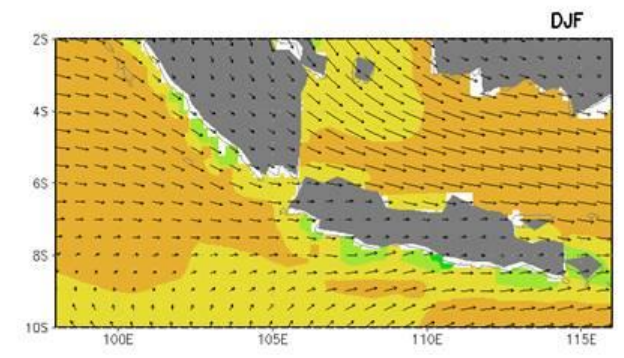

JJA

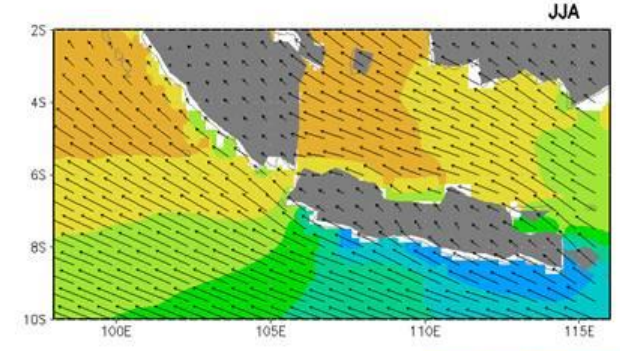

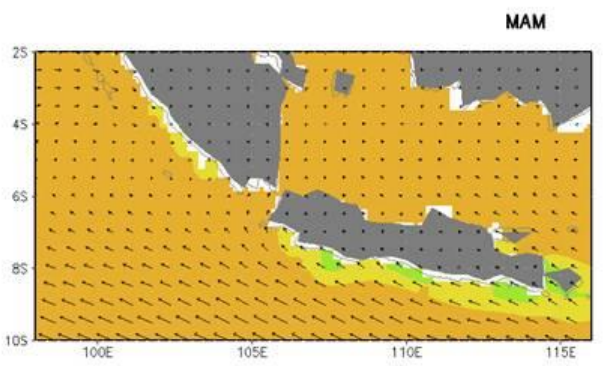

SON

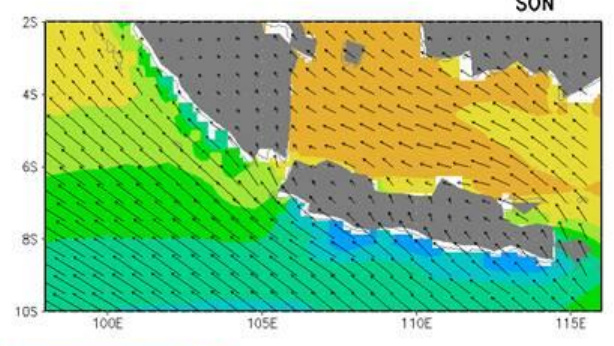

$\overrightarrow{10.0}$

Gambar 2. Komposit SPL dan kecepatan angin permukaan secara musiman di Selatan Jawa.

Distribusi musiman chlorophyll-a di Laut Banda diperlihatkan pada Gambar 3. Konsentrasi chlorophyll-a rata-rata pada bulan April-November mencapai $0,31 \mathrm{mg} / \mathrm{m}^{3}$. Konsentrasi chlorophyll-a pada periode DJF dan MAM terlihat lebih rendah bila dibandingkan dengan konsentrasi chlorophyll-a pada periode JJA dan SON yang mencapai $0,45 \mathrm{mg} / \mathrm{m}^{3}$. Di wilayah ini, periode JJA merupakan periode dengan konsentrasi chlorophyll-a tertinggi dan terdistribusi meluas hingga sekitar $200 \mathrm{~km}$ dari tepi pantai. Kondisi ini terkait dengan sebaran SPL rata-rata pada periode JJA yang mencapai $27,0^{\circ} \mathrm{C}$ dan pada
SON mencapai $28,4^{\circ} \mathrm{C}$ yang disertai angin timuran yang kuat (Gambar 4). Kondisi ini memicu proses upwelling di perairan laut Banda pada periode JJA. Konsentrasi chlorophyll-a mulai terlihat mengalami penurunan pada periode SON dan terus menurun pada DJF hingga MAM. SPL pada periode ini mulai mengalami kenaikan pada SON hingga MAM mencapai nilai maksimum pada periode DJF sebesar $29,5^{\circ} \mathrm{C}$. Pada periode DJF konsentrasi chlorophyll-a sebesar $0,14 \mathrm{mg} / \mathrm{m}^{3}$ terlihat mengalami penurunan, yang mengindikasikan terjadinya proses downwelling. 

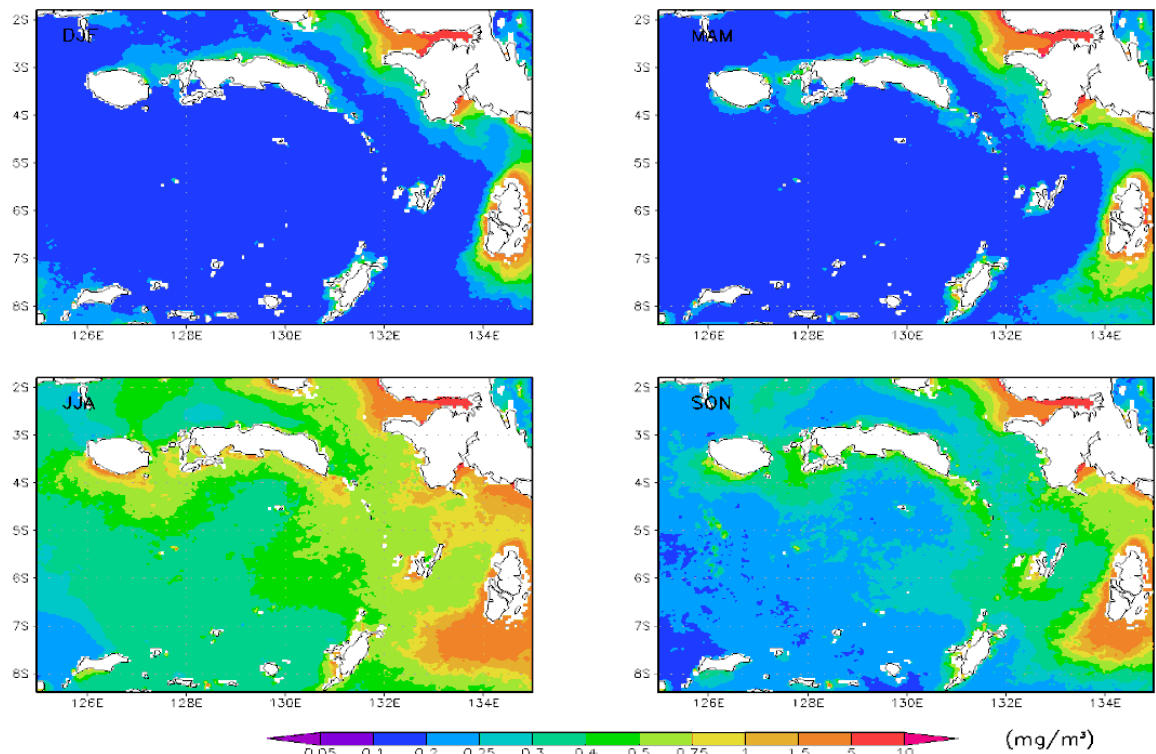

Gambar 3. Komposit chlorophyll-a pada musim DJF, MAM, JJA dan SON di Laut Banda. satuan konsentrasi chlorophyll-a yaitu $\mathrm{mg} / \mathrm{m}^{3}$
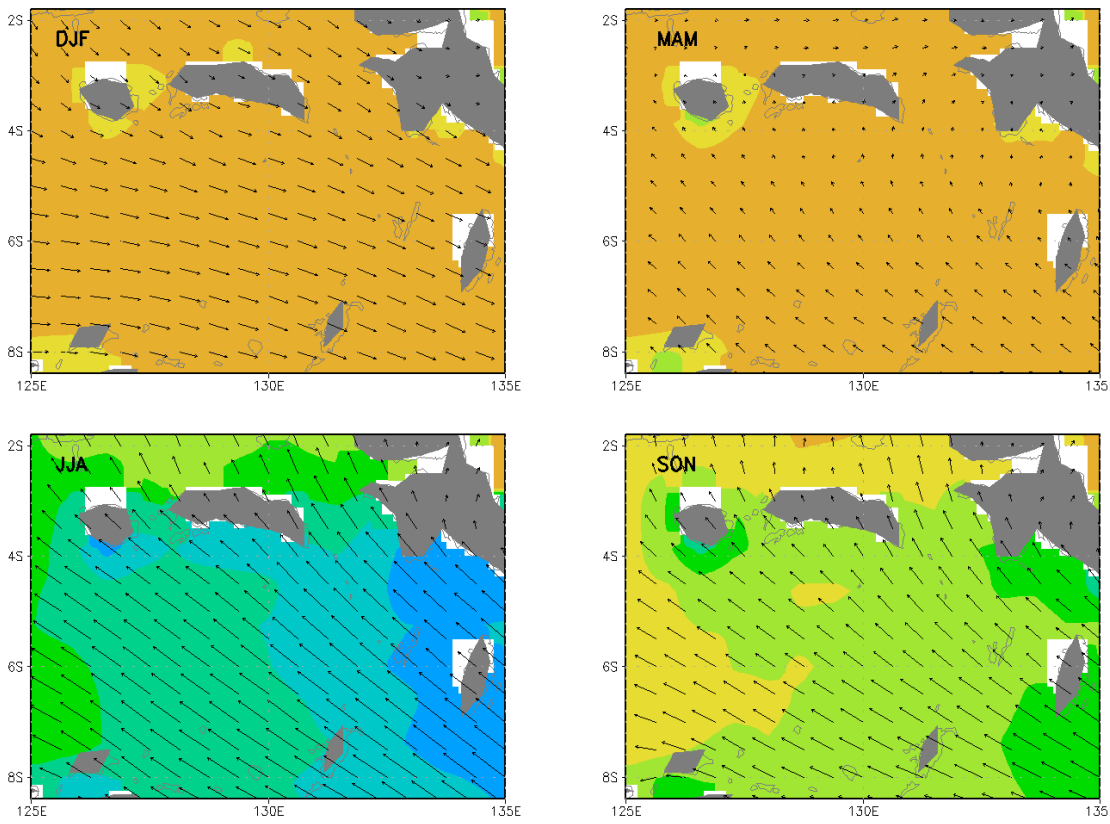

Gambar 4. Komposit SPL dan kecepatan angin permukaan pada musiman DJF, MAM, JJA dan DJF di Laut Banda. Vektor menunjukkan arah dan kecepatan angin.

Kelimpahan konsentrasi chlorophyll-a SPL relatif lebih rendah dan kecepatan angin permukaan yang relatif lebih besar dibandingkan dengan perairan sekitarnya merupakan indikasi terjadinya proses upwelling. Untuk meyakinkan terhadap hasil yang diperoleh dengan metode komposit, estimasi proses fisis upwelling dan downwelling perlu didekati dengan perhitungan ekman transport $M_{E}$ dan ekman pumping $\left(\mathrm{W}_{\mathrm{E}}\right)$. Gambar 5 menunjukkan variasi temporal dari ekman transport, ekman pumping dan chlorophyll-a di Laut Banda dan pesisir selatan Jawa. Hasil perhitungan ekman transport komponen menegak pantai $\left(M_{E y}\right)$ dengan input data gesekan angin (wind stress) komponen sejajar 
pantai $\left(\tau_{x}\right)$ digunakan untuk menganalisis transpor massa air ke arah laut lepas atau menuju pantai. Penelitian Tubalawony et al. (2007), di wilayah perairan barat Sumatera dan selatan Jawa-Sumbawa, menyatakan bahwa ekman transport cenderung bergerak menuju pantai ditandai dengan nilai positif (tanda + ) dan menuju laut lepas ditandai dengan nilai negatif (tanda -). Nilai ekman pumping dihitung dengan input data ekman transport sejajar $\left(M_{x E}\right)$ dan menegak dengan pantai $\left(M_{y E}\right)$. Fenomena upwelling dan downwelling direpresentasikan melalui analisis transport vertikal massa air pada lapisan ekman, dengan perhitungan ekman pumping. Nilai positif (tanda +) dari ekman pumping menunjukan terjadi pengangkatan massa air (upwelling) dan nilai negatif (tanda -) menunjukan tenggelamnya massa air (downwelling), (Tubalawony et al. 2007, Yunwei et al. 2015).

Hasil perhitungan rata-rata ekman pumping di Laut Banda mencapai $2,23 \times 10^{-6} \mathrm{~ms}^{-1}$ pada bulan April-November dan pada periode JJA mencapai $3,65 \times 10^{-6} \mathrm{~ms}^{-1}$ bertepatan dengan berlangsungnya monsun timur. Ekman pumping mencapai mencapai maksimum pada bulan Juli mencapai $4,03 \times 10^{-6} \mathrm{~ms}^{-1}$. Hasil ini sesuai dengan penelitian Gordon dan Susanto (2011c) yakni kecepatan rata-rata ekman pumping di Laut Banda dan Arafuru pada saat upwelling mencapai $2,36 \times 10^{-6} \mathrm{~ms}^{-1}$ pada bulan April-Desember. Tingginya ekman pumping dan melimpahnya chlorophyll-a pada periode ini merepresentasikan terjadinya upwelling di Laut Banda. Nilai ekman transport berdasarkan gesekan angin sejajar pantai selama musim timur terlihat lebih tinggi dibandingkan dengan musim barat. Pola ekman transport sejajar pantai di Laut Banda cenderung mendekati pantai selama monsun timur, sedangkan pada saat berlangsungnya monsun barat pola transport ekman cenderung bergerak menjauhi pantai. Berdasarkan variasi temporal chlorophyll-a dan SST (Gambar 6) saat monsun timur terlihat bahwa konsentrasi chlorophyll-a lebih tinggi dibandingkan dengan konsentrasi pada saat monsun barat. Sementara variasi SST pada saat monsun timur lebih rendah dibandingkan pada saat berlangsungnya monsun barat. Proses upwelling di Laut Banda terjadi secara bergantian dengan proses downwelling. Pada bulan Desember sampai Maret bertepatan dengan berlangsungnya monsun barat terjadi proses downwelling dengan ekman transport yang menjauhi pantai. Hasil perhitungan menunjukkan bahwa ekman pumping lebih dominan berperan dalam proses upwelling di Laut Banda. Selain ekman transport, ekman pumping yang disebabkan oleh wind stress curl secara signifikan dapat meningkatkan proses upwelling lokal (Enriquez dan Friehe, 1995; Castelao dan Barth, 2006; dalam Yunwei et al. 2015; Pickett dan Paduan, 2003) Selama proses ekman pumping, wind stress curl menghasilkan divergensi angin permukaan yang memaksa pergerakan massa air ke permukaan. Jika dibandingkan dengan ekman transport, ekman pumping dapat memberikan kontribusi yang setara atau lebih besar pada beberapa wilayah upwelling (Castelao and Barth,2006; Croquette et al., 2007; Jing et al., 2009; dalam Yunwei et al. 2015; Pickett dan Paduan, 2003). Kondisi ini juga sejalan dengan penelitian Gordon dan Susanto (2011c); Wyrtki (1958), bahwa divergensi pada lapisan permukaan di Laut Banda/Arafuru secara temporal dan profil transpor sebagai pengaruh pergerakan ITF (Indonesian Throughflow) ke Samudra Hindia. Variabilitas SST di Laut Banda juga terkait dengan perubahan kedalaman termoklin yang bervariasi terhadap monsun dan ENSO.

Variasi temporal ekman transport di pesisir selatan Jawa pada saat monsun timur terlihat bergerak menuju laut lepas, sedangkan pada monsun barat ekman transport bergerak menuju pantai. Selama monsun timur ekman pumping menunjukkan terjadinya upwelling sedangkan pada saat monsun barat menunjukkan terjadinya downwelling. Ekman pumping rata-rata pada bulan April-November mencapai $3,51 \times 10^{-6} \mathrm{~ms}^{-1}$, dan mencapai nilai maksimum pada periode JJA mencapai 4,9×10${ }^{6} \mathrm{~ms}^{-1}$. Kondisi ini bersesuaian dengan tingginya konsentrasi chlorophyll-a dan SST yang lebih rendah pada saat monsun timur. Akibat dari transport massa yang menjauhi pantai ini, maka perairan yang kehilangan massa air akan menggerakkan massa air yang lebih dingin dan kaya akan nutrient dari dasar perairan ke permukaan. Massa air yang terangkat ke permukaan ini kaya akan nutrient sehingga menjadi tempat yang subur untuk produsen primer perairan seperti fitoplankton. Analisis ekman pumping dan ekman transport menunjukkan bahwa proses upwelling yang terjadi di selatan Jawa merupakan coastal upwelling yang memiliki dampak signifikan terhadap ekosistem dan perikan (Barth et al, 2007). 

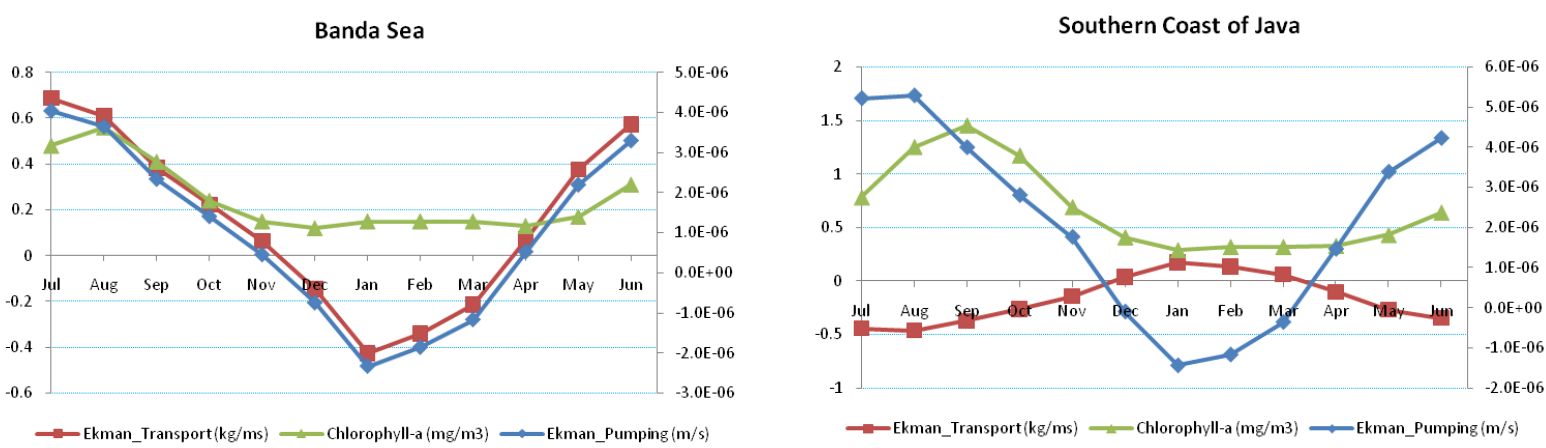

Gambar 5. Variasi temporal Ekman transport, Ekman pumping dan chlorophyll-a bulanan di Laut Banda dan pesisir selatan jawa.
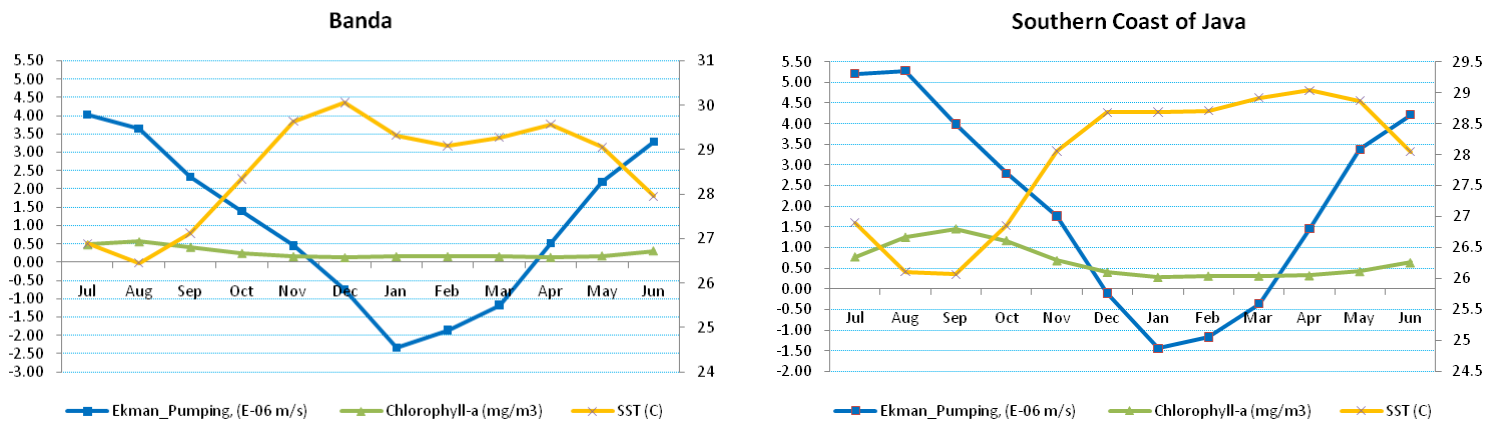

Gambar 6. Variasi temporal Ekman transport, SST dan chlorophyll-a bulanan di Laut Banda dan pesisir selatan jawa.

Menurut Susanto et al. (2001a, 2001b); Susanto dan Marra (2005) bahwa variabilitas iklim antar-tahunan (interannual) (ENSO dan IOD) berpengaruh terhadap distribusi chlorophyll-a di wilayah perairan BMI. Gambar 7 menunjukkan variasi temporal konsentrasi chlorophyll-a di perairan Selatan Jawa dan Laut Banda terkait dengan fenomena El-Nino dan IOD. Pada tahun 2003-2004 terlihat adanya peningkatan chlorophyll-a di selatan Jawa dan di Laut Banda. Hal ini terkait dengan kejadian IOD positif pada tahun tersebut dan El Nino moderat (sedang) tahun 2002-2003 serta El Nino lemah 2004-2005. Peningkatan chlorophyll-a di Selatan Jawa dan di Laut Banda terjadi pada tahun 2006-2007 terkait dengan kejadian El-Nino lemah yang bersamaan dengan IOD positif. Pada tahun 2011-2012 terjadi peningkatan chlorophyll-a di Selatan Jawa dan Laut Banda yang bersamaan dengan lanina lemah dan IOD positif. Peningkatan chlorophyll-a terjadi kembali pada tahun 2015-2016 di selatan Jawa dan di Laut Banda mulai terlihat peningkatan chlorophyll-a pada tahun 20142016. Pada periode tahun 2014-2015 merupakan tahun IOD positif dan Elnino sangat kuat terjadi pada tahun 2015-2016. Variabilitas musiman dan antar-tahunan juga terlihat dari anomali chlorophyll-a dari data ocean color. Pada saat berlangsungnya monsun timur, konsentrasi chlorophyll-a cenderung lebih tinggi dibandingkan pada saat monsun barat. Pada tahun-tahun El Nino dan IOD positif terlihat anomali sebaran chlorophyll-a cenderung lebih tinggi dibandingkan dengan tahun-tahun normal. Fenomena El Nino lemah terjadi pada tahun 2004-2005, 2006-2007; El Nino moderat terjadi pada tahun 2002-2003 dan 2009-2010; El Nino sangat kuat terjadi pada tahun 2015-2016, sedangkan IOD positif terjadi secara bersamaan pada tahun-tahun EI Nino tersebut. Kondisi ini berkontribusi pada peningkatan konsentrasi chlorophyll-a di beberapa wilayah perairan Indonesia, diantaranya perairan selatan Jawa/Sumatra dan Laut Banda. 


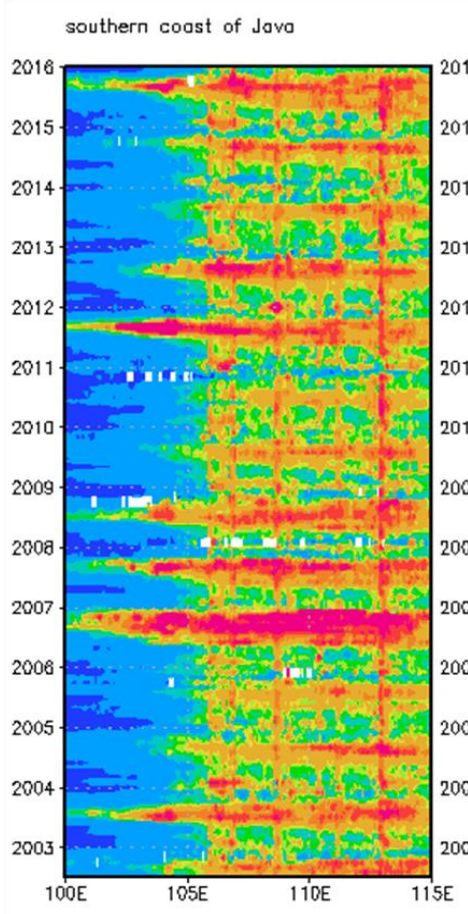

Banda Sea
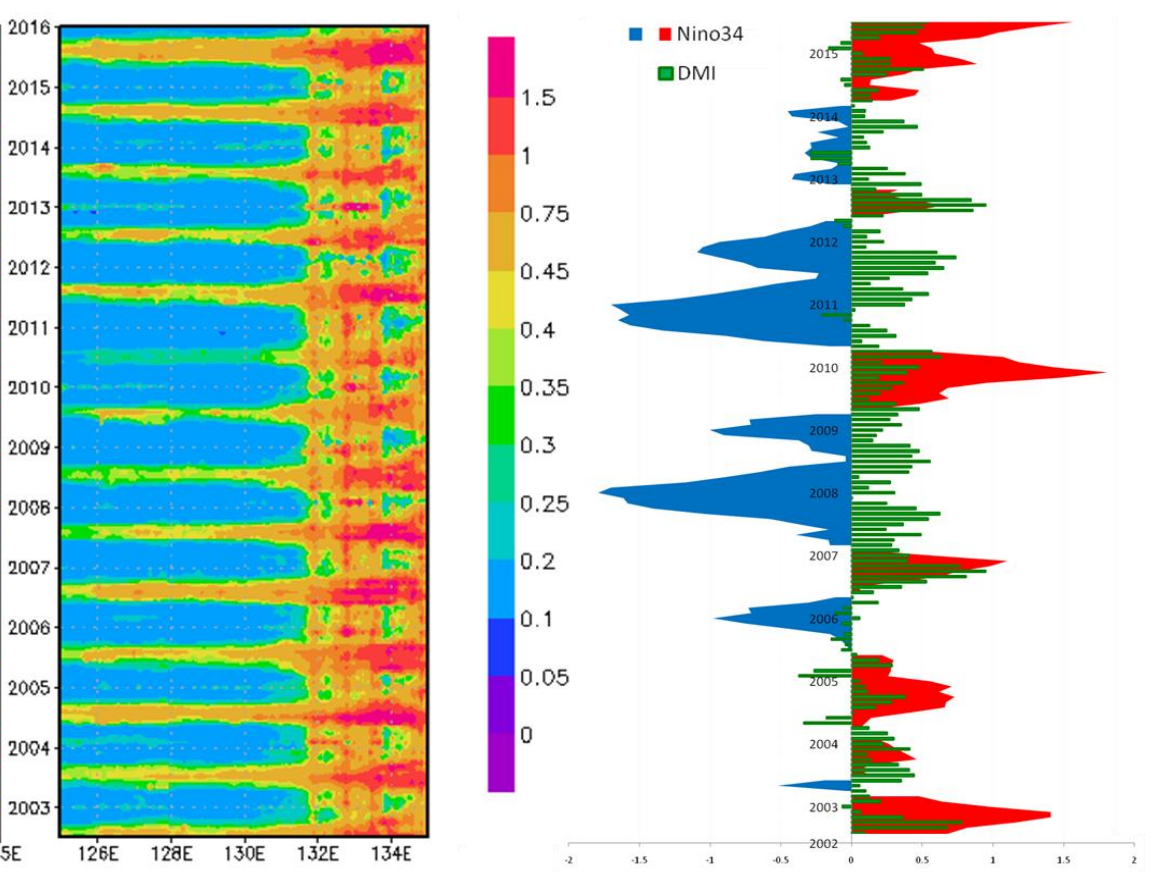

Gambar 7. Variabilitas temporal konsentrasi chlorophyll-a di perairan selatan jawa dan Laut Banda terkait dengan ENSO dan IOD.

\section{Korelasi variabilitas antar-tahunan dengan chlorophyll-a}

Kelimpahan chlorophyll-a pada saat terjadinya IOD positif dan EI Nino terlihat jelas dari Gambar 7. Untuk mengetahui tingkat hubungan antara kelimpahan chlorophyll-a dengan variabilitas iklim antar-tahunan selanjutnya dilakukan analisis korelasi parsial yang dinyatakan sebagai berikut: variabel Nino3.4 $\left(X_{1}\right)$ dan DMI $\left(X_{2}\right)$ dengan chlorophylla $(\mathrm{Y})$. Metode ini diawali dengan melakukan perhitungan korelasi tunggal (korelasi antara dua variabel) kemudian perhitungan terhadap korelasi parsial (korelasi lebih dari dua variabel). Tabel 1, menunjukkan hasil perhitungan korelasi tunggal dengan mengkorelasikan antara masing-masing variabel dan korelasi parsial dengan mengkorelasikan antara 3 variabel dengan salah satu variabel bebas yang dikontrol/dikendalikan/direduksi.

Korelasi parsial dengan satu variabel kontrol (Nino3.4) untuk wilayah Laut Banda dan pesisir selatan Jawa disajikan dalam Tabel 1. Hasil analisis korelasi tunggal antara Chlorophyll-a dengan Nino3.4 dan DMI menunjukkan bahwa di Laut Banda dan perairan selatan Jawa lebih dipengaruhi oleh fenomena IOD dibandingkan dengan kejadian ENSO. Fenomena ENSO memiliki korelasi yang lebih tinggi $(0,24)$ dibandingkan dengan pesisir selatan Jawa $(0,20)$, sedangkan korelasi IOD di Laut Banda lebih rendah $(0,30)$ dibandingkan dengan pesisir selatan Jawa $(0,57)$. Analisis korelasi parsial di Laut Banda dan selatan Jawa antara chlorophyll-a dengan DMI dan Nino3.4 (Nino 3.4 dikendalikan) sebesar 0,25 dan 0,55 pada tingkat kepercayaan 99\% (2-tailed). Hal ini menunjukkan adanya hubungan signifikan antara peningkatan konsentrasi chlorophyll-a di Laut Banda dan selatan Jawa dengan kejadian IOD jika index Nino3.4 dikendalikan/direduksi. Semakin kuat fenomena IOD maka akan terjadi peningkatan konsentrasi chlorophyll-a diwilayah ini.

Tabel 1. Korelasi di Laut Banda dan selatan Jawa

\begin{tabular}{ccccc}
\hline Korelasi & \multicolumn{2}{c}{ Tunggal } & \multicolumn{2}{c}{ Parsial } \\
\hline Area & Nino3.4 & DMI & Nino3.4(DMI dikontrol) & DMI(Nino3.4 dikontrol) \\
\hline Java & $0,20^{*}$ & $0,57^{*}$ & 0,05 & $0,55^{*}$ \\
Banda & $0,24^{*}$ & $0,30^{*}$ & 0,18 & $0,25^{*}$ \\
\hline
\end{tabular}

${ }^{*}$ korelasi signikan dengan taraf 0,01 (2 tailed) 
Analisis korelasi parsial juga digunakan untuk melihat hubungan antara variabel Nino3.4 $\left(X_{1}\right)$ dan DMI $\left(X_{2}\right)$ dengan chlorophyll-a (Y) di Laut Banda dan pesisir selatan Jawa (Tabel 2). Korelasi antara chlorophyll-a dengan Nino3.4 dan DMI di Laut Banda secara signifikan terjadi pada bulan Oktober dan Agustus. Korelasi parsial antara chlorophyll-a dengan Nino3.4 dan DMI (DMI dikendalikan) sebesar 0,57 terjadi terjadi pada bulan Oktober, dan korelasi parsial antara chlorophyll-a dengan DMI dan Nino3.4 (Nino 3.4 dikendalikan) sebesar 0,64 terjadi pada bulan Oktober. Kelimpahan chlorophyll-a pada saat
Nino3.4 positif dan DMI positif secara signifikan terjadi pada bulan Oktober. Korelasi bulanan antara chlorophyll-a dengan Nino3.4 dan DMI di selatan Jawa secara signifikan terjadi pada bulan Mei, Agustus hingga November. Korelasi parsial di selatan Jawa antara chlorophyll-a dengan Nino3.4 dan DMI (dikontrol) secara signifikan sebesar $-0,59$ terjadi terjadi pada bulan Januari dan 0,57 pada bulan Maret, dan korelasi parsial antara chlorophyll-a dengan Nino3.4 (dikontrol) dan DMI secara signifikan terjadi pada bulan Agustus hingga Oktober. Di wilayah selatan Jawa kelimpahan chlorophyll-a lebih dominan terkait dengan fenomena IOD.

Tabel 2. Korelasi di Laut Banda dan selatan Jawa

\begin{tabular}{ccccccccc}
\hline & \multicolumn{9}{c}{ Korelasi } \\
\hline \multirow{3}{*}{ bulan } & \multicolumn{9}{c}{ Banda } & \multicolumn{3}{c}{ Java } \\
\cline { 2 - 9 } & \multicolumn{2}{c}{ Tunggal } & Parsial & Parsial & Tunggal & Parsial & Parsial \\
\cline { 2 - 9 } & Nino3.4 & DMI & DMI & Nino3.4 & Nino3.4 & DMI & DMI & Nino3.4 \\
\hline 1 & 0,26 & $-0,46$ & $-0,52$ & 0,37 & 0,31 & $-0,51$ & 0,46 & $-0,59^{*}$ \\
2 & 0,21 & $-0,09$ & $-0,05$ & 0,20 & 0,34 & 0,20 & 0,29 & 0,39 \\
3 & 0,04 & $-0,26$ & $-0,25$ & 0,02 & $0,55^{*}$ & 0,14 & 0,22 & $0,57^{*}$ \\
4 & 0,02 & 0,16 & 0,16 & $-0,02$ & $-0,06$ & 0,45 & $-0,20$ & 0,48 \\
5 & $-0,03$ & 0,29 & 0,30 & $-0,09$ & 0,10 & $0,56^{*}$ & 0,55 & 0,00 \\
6 & 0,47 & 0,17 & 0,01 & 0,45 & $-0,17$ & 0,45 & 0,55 & $-0,38$ \\
7 & 0,47 & 0,00 & $-0,08$ & 0,48 & 0,05 & 0,52 & 0,52 & $-0,02$ \\
8 & 0,65 & 0,16 & $-0,09$ & $0,64^{*}$ & 0,12 & $0,63^{*}$ & $0,63^{*}$ & $-0,13$ \\
9 & 0,51 & 0,28 & 0,17 & 0,47 & 0,12 & $0,75^{*}$ & $0,75^{*}$ & $-0,13$ \\
10 & $0,68^{*}$ & $0,73^{*}$ & $0,64^{*}$ & $0,57^{*}$ & 0,21 & $0,79^{*}$ & $0,80^{*}$ & $-0,27$ \\
11 & $0,63^{*}$ & $0,60^{*}$ & 0,47 & 0,52 & 0,29 & $0,57^{*}$ & 0,51 & 0,07 \\
12 & $-0,20$ & $-0,33$ & $-0,27$ & 0,06 & 0,24 & 0,23 & 0,08 & 0,11 \\
\hline
\end{tabular}

\section{Kesimpulan}

Proses upwelling yang terjadi di Laut Banda dan perairan Selatan Jawa dapat dijelaskan dari kelimpahan chlorophyll-a secara spasial dan temporal.

1. Konsentrasi chlorophyll-a di Laut Banda pada periode monsun timur JJA $\left(0,45 \mathrm{mg} / \mathrm{m}^{3}\right)$ dan selama monsun barat DJF $\left(0,15 \mathrm{mg} / \mathrm{m}^{3}\right)$. SPL mencapai suhu terendah $27,1^{\circ} \mathrm{C}$ pada periode JJA. Perhitungan ekman pumping rata-rata mencapai $2,23 \times 10^{-6} \mathrm{~ms}^{-1}$ pada bulan April-November saat bersamaan dengan berlangsungnya monsun timur. Ekman pumping mencapai maksimum pada bulan Juli mencapai $4,03 \times 10^{-6} \mathrm{~ms}^{-1}$. Jika dibandingkan dengan ekman transport, ekman pumping memberikan kontribusi yang lebih besar di Laut Banda dalam proses upwelling. Pengangkatan massa air (upwelling) maksimum terjadi pada periode JJA saat monsun timur dengan kondisi perairan SPL relatif rendah, kelimpahan chlorophyll-a tinggi dan ekman pumping yang lebih besar dibandingkan ekman transport menunjukkan proses local upwelling.

2. Di pesisir selatan Jawa, konsentrasi chlorophyll-a musiman pada periode monsun barat, DJF $\left(0,34 \mathrm{mg} / \mathrm{m}^{3}\right)$ sedangkan pada periode monsun timur, JJA $\left(0,89 \mathrm{mg} / \mathrm{m}^{3}\right)$ dan SON $\left(1,1 \mathrm{mg} / \mathrm{m}^{3}\right)$. SPL relatif lebih dingin terjadi pada periode JJA mencapai $27^{\circ} \mathrm{C}$ dan SON mencapai sekitar $26,99^{\circ} \mathrm{C}$. Analisis perhitungan ekman pumping rata-rata pada bulan AprilNovember mencapai $3,51 \times 10^{-6} \mathrm{~ms}^{-1}$, dan maksimum pada periode JJA mencapai $4,9 \times 10^{-6} \mathrm{~ms}^{-1}$. Perhitungan ekman pumping di selatan Jawa menunjukkan adanya 
divergensi ekman transport pada permukaan yang menggerakkan massa air menuju permukaan laut sebagai proses coastal upwelling. Kondisi perairan dengan SST rendah, dan kelimpahan chlorophyll-a tinggi merupakan dampak dari proses coastal upwelling yang teridentifikasi dari tingginya ekman pumping dan ekman transport pada bulan April-November di pesisir Selatan Laut Jawa.

3. Variabilitas iklim antar-tahunan (ENSO dan IOD) terlihat nyata memberikan pengaruh terhadap kelimpahan chlorophyll-a di Laut Banda dan selatan Jawa. Korelasi antara chlorophyll-a dengan Nino3.4 menunjukkan bahwa Laut Banda $(r=0,24)$ lebih terpengaruh oleh fenomena ENSO dibandingkan dengan pesisir selatan Jawa $(r=0.20)$. Sedangkan, korelasi antara antara chlorophyll-a dengan DMI menunjukkan bahwa pesisir selatan Jawa $(r=0,57)$ lebih terpengaruh oleh fenomena IOD dibandingkan dengan Laut Banda $(r=0,3)$.

4. Kombinasi fenomena terjadinya ENSO dan IOD dianalisis dengan teknik korelasi parsial. Korelasi Parsial antara chlorophyll-a dengan Nino3.4 dan DMI (dikendalikan) menunjukkan bahwa Laut Banda lebih terpengaruh oleh ENSO $(r=0,18)$ dibandingkan dengan selatan Jawa $(r=0,05)$. Korelasi Parsial antara chlorophyll-a dengan DMI dan Nino3.4 (dikendalikan) menunjukkan bahwa perairan selatan Jawa lebih terpengaruh oleh IOD $(r=0,55)$ dibandingkan dengan Laut Banda $(r=0,25)$.

5. Upwelling yang terjadi di Laut Banda dan pesisir selatan Jawa lebih dominan akibat terjadi pada saat monsun timur akibat dari pergerakan angin regional yang kuat yang berasosiasi dengan sistem iklim monsun. Pada saat terjadi fenomena ENSO dan IOD, kelimpahan chlorophyll-a akan bervariasi mengikuti kombinasi dari kejadian fenomena tersebut.

\section{Ucapan Terima Kasih}

Artikel ini merupakan bagian dari Tesis Pascasarjana Program Studi Klimatologi Terapan IPB. Penulis mengucapkan terima kasih kepada Badan Pengembangan Sumberdaya Manusia Kelautan dan Perikanan (BPSDMKP), Kementerian Kelautan dan Perikanan (BPSDMKP); Pusat Peneltian Sumberdaya Laut dan Pesisir (P3SDLPBalitbangKP,KKP) atas kesempatan tugas belajar TA 2014 yang telah diberikan. Penulis juga mengucapkan terima kasih kepada Sonny Setiawan M.Si, Nur'utami M.N S.Si dan Andy Syahid M.Si Laboratorium Meteorologi,
Departemen Geofisika dan Meteorologi IPB atas diskusinya.

\section{Daftar Pustaka}

Barth JA, Menge BA, Lubchenco J, et al. 2007. Delayed upwelling alters nearshore coastal ocean ecosystems in the northern California current. Proceedings of the National Academy of Sciences of the United States of America, 104(10): 3719-3724

Duchon, CE. 1979. Lanczos filtering in one and two dimensions. J. Appl. Meteor. 18:1016-1022

Gordon AL and Susanto RD. 2001c. Banda Sea Surface-Layer Divergence. Ocean Dynamic 52: 2-10.

Hidayat, Rahmat., \& Kizu, Shoichi., 2010, Influence of the Madden-Julian Oscillation on Indonesia Rainfall Variability in Austral Summer, Int. J.Clymatology Vol. 30: 1816-1825

Hartanto, M. I., 2011, Variabilitas Klorofil-a dan Interrelasinya terhadap ENSO (EI Nino Southern Oscillation) di Perairan Utara Papua, Tesis, Sekolah Pasca Sarjana, Institut Pertanian Bogor

Hendiarti, N., H. Siegel, and T. Ohde. 2004. Investigation of different coastal processes in Indonesian waters using SeaWiFS data. Deep Sea Research Part II 51:85-97.

Hu C, Lee Z, and Franz B, 2012, Chlorophyll a algorithms for oligotrophic oceans: A novel approach based on three-band reflectance difference, Journal of Geophysical Research, Vol. 117, C01011.

Isoguchi, O., \& Kawamura, $\mathrm{H}_{\text {., 2006, MJO- }}$ Related Summer Cooling and Phytoplankton Blooms in The South China Sea in Recent Years, Geophysical Research Letter, Vol. 33, Li6615, doi:10.1029/2006GL027046

Irianto A. 2006. Statistik: Konsep Dasar dan Aplikasi. Kencana. Jakarta.

Jin, Daeho., Waliser, D.E., Jones, C., \& Murtugudde, R., 2013, Modulation of tropical ocean surface chlorophyll by the Madden-Julian Oscillation, J. Climate Dymanic, Volume 40: 39-58

Kutsuwada K. 1998. Impact of wind/wind-stress field in the North Pacific constructed by 
ADEOS/NSCAT data. J. Oceanogr., 54, 443-456.

Nur'utami, M.N., Hidayat, H., 2016, Influences of IOD and ENSO to Indonesian rainfall variability: role of atmosphere-ocean interaction in the Indo-Pacific sector, Procedia Environmental Sciences 33 ( 2016 ) $196-203$.

Pickett M H, Paduan J D. 2003. Ekman transport and pumping in the California Current based on the US Navy's highresolution atmospheric model (COAMPS). Journal of Geophysical Research: Oceans (1978-2012), 108(C10): doi: 10.1029/2003JC001902

Pond S and GL Pickard. 1983. Introductory dynamical Oceanography. Second edition. Pergamon Press. New York.

Purwandani, Andri, 2012, Variabilitas Suhu Permukaan Laut dan Interelasi-nya dengan Muson, Dipole Mode (DM) dan EI Nino Southern Oscillation (ENSO) di Perairan Asia Tenggara dan sekitarnya, Tesis, Sekolah Pascassarjana, Departemen IImu dan Teknologi Kelautan, Fakultas Perikanan dan IImu Kelautan, Institut Pertanian Bogor

Putra, Ega., 2012. Variabilitas Konsentrasi Klorofil-a dan Suhu Permukaan laut dari Citra Satelit Modis serta Hubungannya dengan Hasil Tangkapan Ikan Pelagis di Perairan Laut Jawa, Skripsi, Departemen IImu dan Teknologi Kelautan, Fakultas Perikanan dan Ilmu Kelautan, Institut Pertanian Bogor

Ramansyah F, 2009, Penentuan Pola Sebaran Konsentrasi Klorofil-a di Selat Sunda dan Perairan Sekitarnya dengan Menggunakan Data Inderaan Aqua Modis, Skripsi, Program Studi IImu dan Teknologi Kelautan, Fakultas Perikanan dan IImu Kelautan Institut Pertanian Bogor,

Saji NH, Goswami BN, Vinayachandran PN,Yamagata T. 1999. A dipole mode in the tropical Indian Ocean. Nature 401:360-363.

Susanto RD, Gordon AL, Zheng Q. 2001a. Upwelling along the coasts of Java and Sumatra and its relation to ENSO. Geophysical Research Letters 28:1,5591,602 .

Susanto RD, Gordon AL, Zheng Q. 2001b. Upwelling within the Indonesian Seas and its relation to Monsoon and ENSO.
The Fifth IOC/WESTPACInternational Scientifi c Symposium, Seoul, Republic of Korea, August 27-31.

Susanto RD, Marra J. 2005. Chlorophyll-a Variability Along the Southern Coasts of Java and Sumatra. Oceanography. Volume 18. Number 4

Tubalawony, Simon., 2000, Karakteristik FisikKimia dan Klorofil-a Laut Timor, Skripsi, Departemen Ilmu dan Teknologi Kelautan, Fakultas Perikanan dan IImu Kelautan, Institut Pertanian Bogor

Tubalawony S, RF Kaswadji, M Purba, S Wouthuyzen dan D Soedharma. 2007. Dampak Proses Fisik Terhadap Sebaran Klorofil.IPB. Bogor

Wheeler MC, Hendon HH. 2004. An all-season real-time multivariate MJO index: Development of an index for monitoring and prediction. Mon. Weather Rev. 132. 1917-1932

Yunwei Yan, Zheng Ling, Changlin Chen. 2015. Winter coastal upwelling off northwest Borneo in the South China Sea. Acta Oceanol.Sin., 34(1) : 3-10 